\title{
PENGUATAN BUDAYA LOKAL DALAM KERANGKA \\ PENDIDIKAN KARAKTER: \\ STUDI PADA BUDAYA JAWA
}

\author{
Adoniati Meyria Widaningtyas \\ riaprastawa@gmail.com \\ Komnas HAM
}

\begin{abstract}
Character education that planned since 2010 by the Ministry of National Education until seven years after the declaration still hasn't shown significant impact for the Indonesian. The issue of globalization and the unstoppable flow of information perceive to begin erode the cultural values that become the identity of the Indonesian nation. Through Presidential Regulation Number 87/2017 on Strengthening Character Education, emphasized the principles of character education, one of which is local wisdom. One of Indonesia's local wisdom is the Javanese culture that characterizes the community in Central Java, East Java and Yogyakarta. This paper aims to explore the values of Javanese culture and relate it to the values of character education developed through strengthening the character education program, as well as giving ideas of its application in school.
\end{abstract}

Keywords: education, character, culture, Java 


\section{PENDAHULUAN}

Dewasa ini masyarakat dunia termasuk Indonesia tengah mengalami perubahan yang disebabkan arus globalisasi dengan nilainilai global yang tak lagi mengenal batas wilayah dan batas negara masuk ke dalam semua sendi kehidupan dan cenderung memarjinalkan nilai-nilai dan budaya lokal berkedok modernisasi. Sebagai bagian dari masyarakat global, warga dunia (global citizenship), bangsa Indonesia tidak dapat menghindari masuknya pengaruh-pengaruh globalisasi baik positif maupun negatif.

Telah banyak penelitian yang menunjukkan terdesaknya atau bahkan memudarnya nilai-nilai budaya lokal dan tak lagi dikenal oleh generasi muda, Nilai-nilai budaya lokal yang masih hidup lebih disebabkan masih adanya para tokoh-tokoh masyarakat, tokoh adat yang mencoba mempertahankan budaya tersebut. Jika hal ini dibiarkan terus menerus, bukan tidak mungkin identitas bangsa Indonesia yang memiliki kultur budaya beragam sebagai identitas bangsa akan hilang dan generasi muda ke depan tak lagi memiliki identitas kebangsaan. Yang penting kemudian dilakukan adalah bagaimana menempatkan diri sebagai warga dunia tetapi tidak tercerabut dari akar budaya bangsa yang dimiliki, bagaimana menjaga kesadaran kebangsaan multikultural melalui penguatan budaya atau kearifan lokal sebagai identitas karakter yang kuat.

Tulisan ini bertujuan menggali nilai-nilai karakter yang berangkat dari budaya dan kearifan lokal dan mengkaitkannya dengan prinsip-prinsip pendidikan karakter, yaitu prinsip ke-5 Kearifan Lokal, dimana gerakan penguatan pendidikan karakter bertumpu dan responsif pada kearifan lokal nusantara yang demikian beragam dan majemuk agar kontekstual dan membumi. Gerakan penguatan pendidikan karakter harus bisa mengembangkan dan memperkuat kearifan lokal nusantara agar dapat berkembang dan berdaulat sehingga dapat memberi identitas dan jati diri peserta didik sebagai bangsa Indonesia.

\section{2}




\section{METODE}

Tulisan ini memusatkan pada budaya Jawa dimana penulis berasal yang juga mendasari metode penelitian melalui studi pustaka dan penelitian kualitatif dengan pengalaman langsung penulis dalam memahami filosofi idiom-idiom dan nilai-nilai budaya Jawa. Pertanyaan utama yang akan dijawab adalah; bagaimana keterkaitan idiom-idiom dan nilai-nilai budaya Jawa dengan nilai-nilai pendidikan karakter?; bagaimana mengintegrasikan dan menginternalisasikan nilai-nilai budaya Jawa dalam pendidikan karakter?

Mengingat antropologi adalah ilmu yang mengkaji tentang kebudayaan atau kebiasaan-kebiasaan yang muncul dan menjadi cara hidup individu atau kelompok sosial dalam bermasyarakat diantaranya cara berfikir, cara bertindak, dan cara merasa yang dimanisfestasikan dalam agama, norma, bahasa dan seni, serta kebiasaan-kebiasaan dalam budaya materi berupa papan, sandang dan pangan, maka sspek kajian antropologi penulis gunakan untuk menganalisis bagaimana antropologi memberi sumbangan kepada pendidikan karakter dengan cara mempelajari kebudayaankebudayaan yang terdapat dalam masyarakat baik yang sederhana maupun modern.

\section{HASIL DAN PEMBAHASAN}

\section{Pendidikan dan Kebudayaan}

Pendidikan adalah pembudayaan karena di dalamnya terdapat proses peneladanan dan pembiasaan. Sebaliknya, pembudayaan adalah proses pencapaian hasil dari pendidikan itu sendiri berupa penghayatan segenap pengetahuan (knowledge) dan keterampilan (skill) yang didapat seseorang melalui pendidikan ke dalam bentuk tindakan nyata (action) yang bermanfaat bagi kehidupannya dan/atau kehidupan orang lain. Ki Hadjar Dewantara dalam pokok-pokok pikirannya memandang pendidikan sebagai daya upaya memajukan 
bertumbuhnya budi pekerti (kekuatan batin dan karakter), pikiran (intellect), dan tubuh anak. Bagian-bagian itu tidak boleh dipisahkan agar dapat memajukan kesempurnaan hidup anak-anak sebagai siswa atau anak didik. Sebagai suatu proses yang bersifat dinamis, pendidikan menurut Ki Hadjar Dewantara menempatkan anak didik sebagai pusat pendidikan, dan mengutamakan keseimbangan antara cipta, rasa, dan karsa dalam diri anak. Pendidikan tidak hanya sekedar proses alih ilmu pengetahuan saja atau transfer of knowledge, tetapi sekaligus pendidikan juga sebagai proses transformasi nilai (transformation of value). Dengan kata lain pendidikan adalah proses pembentukan karakter manusia agar menjadi sebenar-benar manusia, dan pendidikan adalah sarana untuk membentuk karakter bangsa. Pendidikan sebagai usaha kebudayaan yang bermaksud memberi tuntunan di dalam hidup tumbuhnya jiwa raga anak-anak, agar kelak dalam garis-garis kodrat pribadinya dan pengaruh segala keadaan yang mengelilinginya, anak-anak mendapat kemajuan alam hidupnya lahir dan batin menuju ke arah adab kemanusiaan dimana toleransi dijunjung tinggi untuk menghormati hak asasi manusia. ${ }^{1}$

Fuad Hasan dalam tulisannya Pendidikan adalah Pembudayaan2 menyebutkan bahwa pendidikan merupakan ikhtiar pembudayaan demi peradaban manusia, maka pendidikan tidak hanya merupakan prakarsa bagi pengalihan pengetahuan dan keterampilan saja, tetapi juga pengalihan nilai-nilai budaya dan norma-norma sosial. Ilmu pengetahuan sendiri adalah salah satu bentuk kebudayaan yang dihasilkan manusia, melalui ilmu pengetahuan pula kebudayaan dan nilai-nilai yang hidup dapat terus hidup dan diwariskan pada generasi selanjutnya. Proses pembudayaan melalui pendidikan menurut UNESCO dilakukan melalui empat pilar pendidikan, yaitu belajar

1 Haryanto, Pendidikan Karakter Menurut Ki Hadjar Dewantara, Kurikulum dan Teknologi Pendidikan FIP UNY.

2 Tonny D. Widiastono (ed), Pendidikan Manusia Indonesia (Kompas dan Yayasan Toyota Astra, 2004).

\section{4 | Adoniati Meyria Widaningtyas}


untuk mengetahui (learning to know), belajar untuk melakukan (learning to do), belajar hidup bersama (learning to live together), dan belajar untuk mandiri (learning to be).

Korelasi antara pendidikan, kebudayaan dan pembudayaan memunculkan pendekatan pendidikan berbasis budaya itu sendiri. Pendidikan berbasis budaya dimaksudkan bahwa pendidikan yang dilakukan tidak dapat dilepaskan dari tempat, masyarakat dan budaya yang hidup di dalamnya. Pendidikan dipahami sebagai upaya membangun karakter dan identitas, dalam hal ini pendidikan juga sebagai upaya mengenalkan nilai budaya lokal dan kebhinekaan yang dimiliki bangsa Indonesia dalam rangka membangun karakter dan identitas bangsa. Dalam hal ini, H.A.R. Tilaar menegaskan bahwa "Proses pendidikan tidak terjadi di ruang kosong, tetapi dalam ruang manusia yang dialogis. Proses komunikatif-dialogis dapat terhalang apabila lahir hubungan yang bukan timbal balik antar subyek. Pendidikan adalah proses membudaya. Ada tiga jenis masyarakat dengan budayanya: 1) masyarakat tradisional; 2) masyarakat modern; 3) masyarakat transformatif. Di dalam masyarakat transformatif, peranan pendidikan ialah memberikan kemampuan kepada peserta didik yang tetap berpijak pada kebudayaan dengan tradisinya yang masih valid dan dengan aktif menciptakan perubahan yang relevan. Dengan demikian pribadi tidak tercerabut (uprooted) dari kebudayaannya".

Disinilah keterkaitan antara pendidikan dan pengembangan kebudayaan. Pendidikan dan pengembangan budaya sesungguhnya tidak dapat dipisahkan karena sejatinya salah satu tujuan yang hendak diraih oleh proses pendidikan adalah mengantarkan siswa untuk bisa hidup di tengah dan bersama masyarakat guna memelihara dan mengembangkan nilai-nilai luhur budaya tempat mereka lahir dan hidup. Disayangkan ketika kultur sekolah atau bahkan kebijakan pendidikan justru seringkali memisahkan siswa dari nilai-nilai dan kehidupan masyarakat sehingga siswa tidak lagi mengenal nilai-nilai budaya luhur yang hidup di masyarakat. 


\section{Nilai Budaya dalam Pendidikan Karakter}

Budaya menurut Koentjaraningrat adalah keseluruhan sistem gagasan, tindakan, dan segala hasil karya manusia dalam rangka kehidupan masyarakat yang dijadikan milik diri manusia dengan cara belajar. Koentjaraningrat juga menyebut konsep kebudayaan sebagai sistem ide yang dimiliki bersama oleh masyarakat pendukungnya meliputi: (1) kepercayaan; (2) pengetahuan; (3) keseluruhan nilai dan norma hubungan antar individu dalam suatu komunitas yang dihayati, dilakukan, ditaati, dan dilestarikan; (4) keseluruhan cara mengungkapkan perasaan dengan bahasa lisan, tulisan, nyanyian, permainan musik, tarian, lukisan atau penggunaan lambang. 3

Dalam pendekatan metode Brainware Management System $(\mathbb{C}$, budaya memiliki struktur lapisan dari inti budaya (belief) hingga artefak (artifact), sebagai berikut :4

1. Kepercayaan (belief : basic assumptions) merupakan lapisan terdalam sebagai inti budaya;

2. Nilai (values) berfungsi menerjemahkan makna dan semangat dari inti budaya secara konseptual, yang selanjutnya melalui proses interaksi akan membentuk yang dinamakan pola pikir (mindset) manusia, dan termanifestasikan dalam perilaku sesuai norma yang berlaku;

3. Norma (norms) merupakan pembentuk perilaku individu, masyarakat dan bangsa sesuai dengan nilai budayanya;

4. Artefak (artifact) merupakan lapisan budaya terluar sebagai pembentuk tata lingkungan hidup dan kehidupan

3 Soetarno, Ragam Budaya Indonesia (Jakarta: Direktorat Pembinaan Pendidikan Tenaga Kependidikan dan Ketenagaan Perguruan Tinggi Dirjen Dikti Depdiknas, 2004).

4 Iman Sunario dan Bagiono Djokosumbogo, Membangun Budaya dan Peradaban dalam buku Nilai Ke-Indonesia-an (Jakarta: Kompas, 2017). 
masyarakat, termasuk ekspresi budaya seperti kesenian, sastra, cerita rakyat, lagu daerah, ritual adat, adat istiadat daerah, tata kemasyarakatan, relasi sosial dan nilai-nilai adat.

Berangkat dari struktur lapisan budaya tersebut, nilai sebagai struktur kedua dari budaya merupakan keyakinan yang dihayati dalam hidup, diyakini dan menjadi acuan dalam bersikap, bertingkah laku dan bertindak. Nilai menurut Rokeach dalam The Nature of Human Values, memiliki sisi kognitif, afektif dan menyangkut tingkah laku, sehingga kemudian menjadi penting internalisasi diperlukan dalam proses menjadi sebuah karakter perilaku, bukan hanya pengetahuan. Berawal dari pengetahuan seseorang akan sebuah nilai yang hidup dalam sebuah komunitas atau masyarakat, memahaminya sebagai sebuah tatanan atau norma, menginternalisasikan dalam ranah afeksi atau rasa dan berakhir pada sikap hidup dan perilaku seseorang.

Nilai sendiri ada yang berbentuk dan bernilai fisik (tangible) dan ada pula yang tak berbentuk (intangible). Pendidikan sejatinya bekerja dalam ranah nilai yang tak berbentuk (intangible values). UNESCO dalam sebuah konvensi tahun 2003 mendefinisikan nilai atau budaya intangible mencakup practices, representation, expression, knowledge, skill as well as the instruments, artifact and cultural spaces associated therewith that communities, groups and in some cases, individuals recognize as part of their cultural heritage (praktik, representasi, ekspresi, pengetahuan, keterampilan serta instrumen, artefak dan ruang budaya yang terkait dengannya, masyarakat, kelompok dan dalam beberapa kasus, pengakuan individu sebagai bagian dari warisan budaya mereka). Inilah yang kemudian kita kenal sebagai kearifan lokal (local wisdom) atau nilainilai budaya lokal. Dan kekayaan bangsa Indonesia akan nilai-nilai budaya lokal seharusnyalah menjadi dasar pula bagi upaya-upaya membangun karakter bangsa Indonesia melalui pendidikan karakter atau penumbuhan budi pekerti. 
Karakter menurut Kamus Besar Bahasa Indonesia diartikan sebagai sifat atau ciri kejiwaan, tabiat, watak, akhlak atau budi pekerti, yang membedakan seseorang dari yang lain. Karakter adalah cara berpikir dan berperilaku yang menjadi ciri khas tiap individu untuk hidup dan bekerjasama baik dalam lingkup keluarga, masyarakat, bangsa dan negara. Pendidikan karakter adalah pendidikan budi pekerti yang melibatkan aspek pengetahuan atau kognitif (moral knowing), perasaan atau afektif (moral feeling) dan tindakan (moralaction), yang menurut Thomas Lickona pendidikan karakter tanpa melingkupi ketiga aspek tersebut tidak akan efektif. Moral knowing disini meliputi kesadaran moral, pengetahuan mengenai nilai, perspektif dalam bersikap, penalaran atas sebuah nilai atau moral, membuat keputusan dan pengetahuan akan diri pribadi. Moral feeling meliputi nurani, penghargaan diri, empati, kebaikan, kontrol diri, dan rendah hati, sedangkan yang termasuk dalam moral action adalah kompetensi, kehendak dan kebiasaan.

Pendidikan menurut Metta Spencer dan Alex Inkeles berfungsi sebagai transmitting values dan transmitting culture atau pewarisan nilai dan budaya yang dilakukan oleh generasi pendahulu pada generasi berikutnya. Proses transfer dilakukan melalui pembiasaan pada anak didik atau siswa dengan menggali, mengenal, mempelajari, memahami, menguasai, menginternalisasikan dan menerapkan nilainilai budaya tersebut untuk kebaikan dirinya, keluarganya, komunitas, masyarakat dan bangsa serta membangun peradabannya di masa depan. Sementara, menurut T. Ramli pendidikan karakter hakikatnya adalah pendidikan nilai yaitu nilai-nilai yang berasal dari nilai-nilai sosial budaya bangsa, nilai moral universal (bersifat absolut) dan nilai-nilai agama. Pendidikan karakter yang berbasis pada budaya lokal ibaratnya learning by doing, belajar akan nilai-nilai karakter yang hidup dalam budaya dengan melakukan norma-norma sikap dan perilaku dalam kehidupan kesehariannya. 
Undang-undang No. 20 Tahun 2003 tentang Sistem Pendidikan Nasional pasal 1 ayat (2) mengatur bahwa : "Pendidikan Nasional adalah pendidikan yang berdasarkan Pancasila dan Undang-Undang Dasar Negara Republik Indonesia Tahun 1945 yang berakar pada nilai-nilai agama, kebudayaan nasional Indonesia dan tanggap terhadap tuntutan perubahan zaman." Selanjutnya pada pasal 4 ayat (1) menyebutkan bahwa: "Pendidikan diselenggarakan secara demokratis dan berkeadilan serta tidak diskriminatif dengan menjunjung tinggi hak asasi manusia, nilai keagamaan, nilai kultural, dan kemajemukan bangsa". Mendasarkan pada kedua pasal tersebut, penyelenggaraan pendidikan hendaknya mengenalkan dan mengembangkan sikap-sikap yang menghargai orang lain dengan segala perbedaannya, sikap-sikap respek dan empati, sikap toleransi, tidak diskriminatif, keadilan, gotong royong, musyawarah dan kekeluargaan. Nilai-nilai agama, nilai-nilai kultural dan kemajemukan bangsa haruslah dilihat sebagai sebuah kekayaan bagi dunia pendidikan dimana menjadi dasar bagi sekolah dan guru untuk mengenalkan kearifan lokal (local wisdom) dan keberagaman budaya yang dimiliki bangsa Indonesia pada siswanya sejak dini sebagai dasar pembentukan karakter bangsa.

Untuk itu, pendidikan nilai dan karakter haruslah mampu mengembangkan seluruh potensi yang secara sistemik terkait satu dengan yang lain dalam rangka membangun karakter pribadi yang: 1 ) dengan Tuhan bertakwa atau religius; 2) dengan diri sendiri bersikap jujur, bertanggung jawab, disiplin, sehat, kerja keras, percaya diri, kreatif, inovatif, mandiri, memiliki rasa ingin tahu dan ingin berkembang; 3) dengan sesama dan lingkungan sadar akan hak dan kewajiban, sadar akan aturan sosial, saling menghargai satu sama lain, sopan santun, demokratis, gotong royong, rukun, peduli dan solidaritas; serta 4) dengan bangsa, negara dan dunia memiliki nasionalisme, menghargai keberagaman, menghargai budaya dan mampu menjadi warga negara dan warga dunia. 


\section{Budaya Jawa dalam Konsep Etika}

- Jawa sebagai salah satu wilayah yang memiliki keberagaman kearifan lokal atau budaya. "Budaya Jawa" merupakan dua kata yang terdiri dari "budaya" dan "Jawa". Budaya dan kebudayaan menurut para ahli antropologi memiliki makna yang sama. Apabila budaya diartikan dari paduan kata budi dan daya, maknanya daya dari budi, maka daya dari budi mewujud pada tiga hal atau tiga wujud kebudayaan yaitu sistem ide, aktivitas dan hasil karya. Sedangkan Jawa menunjuk pada nama suku di Indonesia yaitu suku Jawa. Dengan demikian budaya jawa dapat diartikan sebagai kebudayaan yang dimiliki oleh suku Jawa yang biasanya diikuti oleh masyarakat Jawa Tengah, Jawa Timur dan Yogjakarta. Kearifan lokal budaya Jawa5 tersebut dapat dilihat melalui:

1.Norma-norma lokal yang dikembangkan, seperti laku Jawa, pantangan dan kewajiban,

2.Ritual dan tradisi masyarakat Jawa serta makna di baliknya,

3.Lagu-lagu rakyat, legenda, mitos, dan cerita rakyat Jawa yang biasanya mengandung pelajaran atau pesan-pesan tertentu,

4.Informasi data dan pengetahuan yang terhimpun pada diri sesepuh masyarakat pemimpin spiritual,

5.Cara-cara komunitas lokal masyarakat Jawa dalam memenuhi kehidupannya sehari-hari,

6.Alat dan bahan yang dipergunakan untuk kebutuhan tertentu, dan

7.Kondisi sumber daya alam atau lingkungan yang biasa dimanfaatkan dalam kehidupan masyarakat sehari-hari.

\footnotetext{
5 Hidayat Widiyanto, Prosiding Kearifan Lokal Budaya Jawa sebagai Bahan Ajar Bahasa Indonesia bagi Penutur Asing (BIPA, 2010).
} 
Salah satu sumber dan wujud kearifan lokal yang berasal dari budaya Jawa adalah etika Jawa dimana terkandung tata nilai kehidupan Jawa, seperti norma, keyakinan, kebiasaan, konsepsi, dan simbol-simbol yang hidup dan berkembang dalam masyarakat Jawa, misalnya tepa slira, rukun, andhap asor, unggah-ungguh, mawas diri, dan sebagainya. Etika Jawa secara garis besar disampaikan melalui dua cara. Pertama, melalui pituduh (wejangan, anjuran) yang isinya memberikan nasihat berupa anjuran. Kedua, melalui pepali (wewaler) artinya larangan agar orang Jawa menjauhi perbuatan yang tidak baik. Nasihat dan larangan merupakan inti budi pekerti atau etika. Tujuan pemberian nasihat dan larangan adalah keadaan selamat atau slamet. Budi pekerti atau etika bagi masyarakat Jawa merupakan suatu keharusan. Budi pekerti atau etika Jawa disampaikan dari pihak tertentu kepada pihak lain yang memiliki posisi tidak sama (bertingkat). Dalam budaya Jawa, penyampaian nasehat atau larangan seringkali dilakukan dalam bentuk budaya simbol. Hampir semua kehidupan orang Jawa dipenuhi dengan simbol yang di setiap simbolnya memuat pesan dan nilai-nilai luhur. Bahkan untuk menjaga atau menghindari konflik, orang Jawa sering menyampaikan pesan moralnya dengan bahasa-bahasa semu bahkan orang tuapun sering mengajarkan nilai-nilai kepada anaknya dengan perumpamaan atau disebut sasmita.

Ki Tyasno, Ketua Umum Majelis Hukum Taman Siswa menyatakan bahwa dasar filosofi karakter bagi masyarakat Jawa adalah Tri Rahayu (tiga kesejahteraan) yang merupakan nilai-nilai luhur dan merupakan pedoman hidup meliputi: 1) Mamayu hayuning salira (bagaimana hidup untuk meningkatkan kualitas diri pribadi); 2) Mamayu hayuning bangsa (bagaimana berjuang untuk negara dan bangsa); dan 3) Mamayu hayuning bawana (bagaimana membangun kesejahteraan dunia). Untuk mencapai Tri Rahayu tersebut, manusia harus memahami, menghayati, serta melaksanakan tugas sucinya sebagai manusia yang tercantum dalam Tri Satya Brata (tiga ikrar bertindak) yaitu: 1) Rahayuning bawana kapurba waskitaning manungsa (kesejahteraan dunia bergantung kepada manusia yang 
memiliki ketajaman rasa); 2) Dharmaning menungsa mahanani rahayuning nagara (tugas utama manusia adalah menjaga keselamatan negara); dan 3) Rahayuning manungsa dumadi karana kamanungsane (keselamatan manusia ditentukan pada tata perilakunya, rasa kemanusiaannya). Disisi yang lain, Ki Ageng Soerjomentaram mengutarakan bahwa dalam menjalani hidup ini sebaiknya manusia "tidak" melakukan tiga hal yaitu ngangsa-angsa (ambisius, bernafsi-nafsi), ngaya-aya (terburu-buru, tidak teliti, cermat dan hati-hati), dan golek benere dhewe (mencari benarnya sendiri, mau menang sendiri).

Etika Jawa dijalankan sebagai usaha untuk menjaga keselarasan hidup dan keharmonisan hubungan antar manusia, sehingga dikenal dua nilai utama dalam etika Jawa yaitu nilai rukun dan nilai hormat. Nilai rukun adalah nilai dimanamasyarakat Jawa memegang teguh keyakinan bahwa rukun merupakan sebuah kondisi untuk mempertahankan masyarakat yang harmonis, tentram, aman, dan tanpa perselisihan. Nilaihormat, yaitu nilai yang berkaitan erat dalam hubungannya dengan orang lain, dengan kata lain mencakup relasi sosial. Dalam konteks nilai hormat, lebih jauh dalam masyarakat Jawa terdapat sebuah hirarki yang membatasi mereka untuk bersikap kepada orang lain. Misalnya, hubungan antara orang tua-anak dan antar teman sebaya.

Etika dalam masyarakat Jawa memiliki dimensi yang sangat luas, yaitu mencakup etika kepada Sang Maha Pencipta, etika kepada sesama manusia, dan etika kepada alam semesta. Manusia dikatakan menjadi manusia yang sebenarnya apabila ia menjadi manusia yang beretika yakni manusia yang secara utuh mampu memenuhi hajat hidup dalam rangka mengasah keseimbangan antara kepentingan pribadi dengan kepentingan sosial, antara rohani dan jasmani, antara manusia sebagai makhluk dengan Penciptanya. 


\section{Penguatan Budaya Jawa dalam Pendidikan Karakter}

Melihat kembali fungsi pendidikan karakter yang dikembangkan Kementerian Pendidikan dan Kebudayaan sejak tahun 2010 yang meliputi (1) mengembangkan potensi dasar agar berhati baik, berpikiran baik dan berperilaku baik; (2) memperkuat dan membangun perilaku bangsa yang multikultur; (3) meningkatkan peradaban bangsa yang kompetitif dalam pergaulan dunia, dimana salah satu prinsipnya adalah kearifan lokal, maka tidaklah berlebihan jika mengatakan bahwa nilai-nilai etika Jawa berikut ini jika dikaitkan dengan situasi perkembangan jaman atau peradaban saat ini masih sangat relevan. Nilai-nilai etika Jawa tersebut dapat diintegrasikan melalui pendidikan penumbuhan budi pekerti dan penguatan pendidikan karakter bagi generasi muda, antara lain: 6

\section{Eling Sangkan Paraning Dumadi}

Manusia Jawa berkeyakinan bahwa urip ana sing nguripake (hidup ada yang menghidupkan) dan suatu saat akan kembali kepada yang menghidupkan, yaitu Tuhan. Nasihat inimenjadi pengingat agar manusia selalu menjaga sikap dan perbuatan di dunia karena kelak akan diminta pertanggungjawabannya di hadapan Tuhan. Sehingga dalam menjalani hidup manusia Jawa akan senantiasa golek dalan padhang, berbuat lurus, tidak melakukan hal-hal yang dilarang Tuhan. Sikap-sikap tersebut menunjukkan religiusitas masyarakat Jawa.

\section{Urip Samadya}

Dalam menjalani hidup, orang Jawa memiliki sikap samadya mengukur kemampuannya, tidak memaksakan kehendak untuk meraih sesuatu yang tidak mungkin diraihnya. Sikap hidup

6 Bekti Patria, "Etika Jawa: Sumber Kearifan Lokal Sebagai Sarana Pembentuk Karakter Siswa", https://bektipatria.wordpress.com/2012/07/15/pendidikan-karaktermelalui-etika-jawa/ 
samadya menjauhkan seseorang dari perbuatan yang menghalalkan segala cara untuk mendapatkan yang diinginkannya.

3. Rereh, Ririh, dan Ngati-ati.

Rereh, artinya sabar dan bisa mengekang diri. Ririh, artinya tidak tergesa-gesa dalam bertindak, mempunyai pertimbangan matang untuk sebuah tindakan dan keputusan. Ngati-ati, artinya berhatihati dalam bertindak. Dengan sikap rereh, ririh, dan ngati-ati, berarti manusia dapat menguasai dirinya, menguasai nafsunya dan menjauhkan dari konflik.

4. Membenci watak adigang, adigung, adiguna.

Watak adigang adalah watak sombong, karena mengandalkan kekayaan dan pangkat. Watak adigung adalah watak sombong karena mengandalkan kepandaian dan kepintaran, cenderung meremehkan orang lain. Watak adiguna adalah watak sombong karena mengandalkan keberanian dan kepintaran berdebat. Sikap ini menjadikan seseorang bersikap sapa sira sapa ingsun, yang merupakan gambaran sikap sombong. Oleh karena itu, sikap-sikap ini harus dihindari. Seseorang justru harus bersikap ramah dan menghargai sesama manusia. Jangan berlaku seolaholah menjadi manusia yang "paling".

5. Aja Dumeh

Kata ini mengandung maksud "jangan mentang-mentang" dan dapat diterapkan dalam berbagai sikap dan perbuatan, misalnya aja dumeh pinter, aja dumeh kuasa, aja dumeh kuwat, dan sebagainya. Sikap hidup aja dumeh akan membawa seseorang pada sikap rendah hati, sederhana, tidak merasa "paling" dibandingkan dengan orang lain di sekitarnya.

6. Mawas Diri

Mawas diri adalah tindakan untuk melihat ke dalam diri sendiri, mengukur nilai dan kemampuan diri. Dengan mawas diri 
seseorang akan selalu berupaya melihat kekurangan diri sendiri. Sikap ini menumbuhkan rasa saling menghargai sesama.

7. Tepa Slira

Tepa slira berarti tenggang rasa, toleransi, menghargai orang lain, nepakke awake dhewe. Apabila kita merasa senang dan bahagia jika orang lain berperilaku baik kepada kita, maka hendaknya kita juga berusaha bersikap baik terhadap orang lain. Tepa slira adalah sikap individu untuk mengontrol pribadinya berdasarkan kesadaran diri. Wujud sikap tepa slira adalah sikap menjaga hubungan baik dengan sesama sebagai anggota masyarakat dan tidak akan mburu menange dhewe, nggugu karepe dhewe, dan nuhoni benere dhewe, sehingga kehidupan akan lebih damai.

8. Unggah-Ungguh, Suba Sita, Empan Papan

Unggah-ungguh merupakan salah satu bentuk etika atau sikap manusia Jawa dalam menempatkan diri ketika bergaul dengan sesamanya. Seseorang yang memiliki dan memahami sikap unggah-ungguh akan mengetahui bagaimana cara bergaul dan berperilaku dengan orang yang lebih muda, sederajat, lebih tua, atau yang memiliki jabatan tertentu, bahkan dalam situasi tertentu.

9. Jujur

Jujur merupakan karakter yang sifatnya universal. Masyarakat Jawa pun menganggap sikap jujur sebagai etika yang harus dipegang teguh dan dimiliki oleh setiap orang Jawa. Hal ini tercermin dalam ungkapan-ungkapan Jawa seperti, jujur bakal mujur, artinya orang yang jujur akan mendapatkan keberuntungan. Keberuntungan yang didapatkan oleh orang jujur sesungguhnya tidak serta merta dan tidak hanya bersifat fisik. Artinya keberuntungan itu bisa jadi baru didapatkannya kelak dan hanya bisa dirasakan oleh batin. Oleh karena itu, sikap jujur jangan sampai ditinggalkan dan tetap yakin bahwa becik ketitik 
ala ketara, kebaikan akan terlihat dan keburukanpun akan tampak nyata.

10. Rukun

Hidup rukun selalu menjadi dambaan manusia yang hidup bermasyarakat. Demikian pula pada masyarakat Jawa yang juga mendambakan kehidupan yang selalu cinta damai. Cinta damai dapat terwujud jika antar sesama anggota masyarakat tersebut dapat hidup rukun. Sehingga dalam masyarakat Jawa terdapat ungkapan rukun agawe santosa, yaitu bahwa hidup rukun sesama manusia akan membuat kehidupan menjadi sentosa.

11. Kerja keras

Manusia Jawa tidak boleh lalai untuk selalu berupaya mencukupi kebutuhannya, oleh karenanya harus senantiasa bekerja keras sehingga akan mampu hidup mandiri dan layak tanpa bergantung pada belas kasihan orang lain. Sikap hidup semacam ini tercermin dalam ungkapan Jawa sapa ubet, ngliwet yaitu siapa yang kreatif dalam berusaha mencari rezeki, maka pasti akan mendapatkan hasilnya. Di samping itu, dalam bekerja manusia Jawa juga berprinsip bahwa bekerja tidak melihat pada besar kecilnya hasil yang harus diperoleh, tetapi lebih mementingkan apa yang harus dikerjakan. Hasil menjadi perkara belakangan, sebagaimana ungkapan sepi ing pamrih, rame ing gawe. Etos kerja ini sangat luar biasa karena menunjukkan semangat pengabdian yang besar. Orang yang bekerja dengan semangat pengabdian ini sangat diperlukan dalam membangun bangsa.

12. Tanggung jawab

Tanggung jawab merupakan sikap yang juga harus dimiliki oleh manusia Jawa. Sehingga dalam masyarakat Jawa ditemukan juga ungkapan tinggal glanggang colong playu yang arti harfiahnya meninggalkan gelanggang dan secara diam-diam melarikan diri. Ungkapan ini merupakan sindiran bagi seseorang yang suka

\section{6 | Adoniati Meyria Widaningtyas}


lepas tangan, cuci tangan dari tanggung jawab yang seharusnya diembannya.

\section{Rumangsa Melu Handarbeni, Rumangsa Wajib Hangrungkebi}

Merasa ikut memiliki, merasa wajib membela. Dengan merasa memiliki orang akan punya keinginan untuk menjaga dan melestarikan serta membela sesuatu yang menjadi miliknya. Bila generasi muda memiliki sikap ini mereka akan berupaya untuk turut berperan dalam memperbaiki kondisi bangsa dan tidak justru merusak citra bangsa.

14. Memayu Hayuning Bawana

Memayu berarti membuat selamat, bawana berarti bumi. Memayu hayuning bawana merupakan sikap dan tindakan untuk menjaga keselamatan dan kelestarian bumi. Bila bumi terjaga maka manusia juga terhindar dari bencana, seperti banjir, tanah longsor, kekeringan, dan sebagainya. Memayu hayuning bawana juga bisa diterjemahkan sebagai sikap dan tindakan menjaga keselamatan bumi dari segi ketenteraman dan kedamaian.

Keempat belas nilai dalam etika Jawa tersebut jika dipersandingkan dengan 18 nilai karakter yang dikembangkan dalam pendidikan karakter sesuai Peraturan Presiden No. 87 Tahun 2017 tentang Penguatan Pendidikan Karakter akan nampak keterkaitan bukan perbedaan, bahkan saling menguatkan. Kedelapan belas nilai karakter tersebut adalah religius, jujur, toleransi, disiplin, kerja keras, kreatif, mandiri, demokratis, rasa ingin tahu, semangat kebangsaan, cinta tanah air, menghargai prestasi, bersahabat/komunikatif, cinta damai, gemar membaca, peduli lingkungan, peduli sosial dan tanggung jawab.

\section{Pelaksanaan Pendidikan Karakter Berbasis Budaya Jawa}

Pendidikan karakter berbasis kearifan budaya lokal pada dasarnya memiliki empat pilar utama yang meliputi: (1) membangun manusia 
berpendidikan harus berlandaskan pada pengakuan eksistensi manusia sejak dalam kandungan; (2) pendidikan harus berbasis kebenaran dan keluhuran budi, menjauhkan dari cara berpikir tidak benar dan grusa-grusu atau watonsulaya; (3) pendidikan harus mengembangkan ranah moral, spiritual (ranah afektif) bukan sekedar kognitif dan ranah psikomotorik; dan (4) sinergitas budaya, pendidikan dan pariwisata perlu dikembangkan secara sinergis dalam pendidikan yang berkarakter. Untuk itu, pendidikan karakter berbasis budaya Jawa diharapkan bukan memulai sesuatu yang baru tetapi bagaimana menguatkan pendidikan karakter yang telah ada dengan memperhatikan dimensi-dimensi yang harus dikembangkan meliputi:

1. Content integration, yaitu mengintegrasikan nilai-nilai etika Jawa dalam kategorisasi 18 nilai karakter dengan mengilustrasikan konsep mendasar, generalisasi dan teori dalam mata pelajaran atau disiplin ilmu;

2. The knowledge construction process, yaitu membawa siswa untuk memahami implikasi nilai-nilai etika Jawa sebagai bagian dari pendidikan karakter ke dalam semua mata pelajaran atau disiplin ilmu;

3. An equity paedagogy, yaitu menyesuaikan metode pembelajaran dengan cara belajar siswa dalam rangka memfasilitasi prestasi akademik siswa yang beragam baik dari segi ras/etnis, budaya, suku, agama ataupun sosial;

4. Prejudice reduction, yaitu mengidentifikasi karakteristik siswa dan menentukan metode pembelajaran yang tepat, membangun interaksi yang terbuka dalam rangka menciptakan budaya akademik yang berkarakter.

Hal terpenting dalam mengembangkan metode pendidikan berbasis budaya adalah: 1) cari nilai-nilai positif dari budaya Jawa yang ada; 2) cari kesamaan nilai dengan keberagaman budaya yang lain; 3) buka ruang diskusi siswa untuk mengaitkan nilai-nilai budaya 
Jawa dengan nilai-nilai budaya lain dan juga 18 nilai-nilai karakter maupun sebaliknya; 4) ajak siswa aktif mengembangkan nilai-nilai budaya Jawa, keberagaman budaya dan nilai-nilai karakter melalui kegiatan kurikuler, kokurikuler dan ekstrakurikuler; dan 5) buka ruang-ruang perjumpaan diantara keberagaman yang ada di sekolah atau antar sekolah sebagai praktek riil siswa membiasakan penerapan nilai-nilai karakter berbasis budaya lokal (sikap, tindakan, ucapan, interaksi, komunikasi).

Nilai-nilai etika Jawa sebagai sumber pendidikan karakter setidaknya harus dibawa pada dua fungsi, yaitu edukatif dan kultural. Fungsi edukatif diarahkan agar siswa dapat memperoleh nilai-nilai budaya Jawa untuk keperluan pembentukan kepribadian dan identitas bangsa. Melalui pembelajaran unggah-ungguh atau tata cara etika Jawa seperti diuraikan sebelumnya kepada siswa dapat ditanamkan nilai-nilai sopan santun. Dalam fungsi edukatif ini dapat juga dilakukan melalui pembelajaran bahasa, pembelajaran berbagai karya sastra Jawa seperti wayang, ketoprak atau buku-buku sastra misalnya, selain berfungsi sebagai pertunjukan seni, bacaan literasi juga berfungsi sebagai tuntunan (pendidikan). Melalui pertunjukan wayang dan ketoprak, siswa dapat ditanamkan nilai-nilai etika, estetika, sekaligus logika melalui percakapan dan alur ceritanya yang banyak mengandung nilai-nilai lokal Jawa untuk kepentingan pendidikan.

Sedangkan, fungsi kultural adalah agar siswa dapat menggali kembali nilai-nilai budaya Jawa sebagai upaya untuk membangun identitas dan karakter bangsa. Kedua fungsi tersebut jika dilihat dari substansi nilai, merupakan usaha pengembangan dan penanaman nilai-nilai moral. Fungsi kultural dapat terlaksana ketika fungsi edukatif terlaksana. Melalui fungsi edukatif diharapkan telah ditanamkan nilai-nilai kepribadian luhur sebagai bagian dari dari tata nilai dan budaya Jawa. Jika penanaman nilai-nilai budaya Jawa telah berhasil, maka akan terbangun kepribadian yang kuat, dan pada akhirnya akan membentuk karakter yang kuat pula. 
Praktek pelaksanaan penguatan pendidikan karakter berbasis budaya Jawa dapat dilakukan melalui: (1) integrasi melalui kurikulum dan mata pelajaran, misalnya masuk dalam RPP; (2) integrasi melalui muatan lokal; (3) integrasi melalui ekstrakurikuler; dan (4) integrasi melalui pengembangan diri atau karakter. Selain melakukan pengintegrasian nilai-nilai etika Jawa melalui keempat jalur tersebut diharapkan juga dapat memfasilitasi siswa untuk menggali nilai-nilai budaya Jawa yang ada serta menyelaraskan dan mengkontekskannya dengan nilai-nilai pendidikan karakter.

Pada aspek metode, Prof. Azyumardi Azra menekankan pada pentingnya model-model pembelajaran dengan pendekatan kritis (critical thinking) baik bagi guru maupun siswa di berbagai jenjang pendidikan. Penggalian metode-metode yang inovatif, kreatif, analitis, partisipatif dan memberdayakan (empowering) dan pengetahuan terhadap budaya dan kearifan lokal serta kebudayaan bangsa penting terus dikembangkan oleh guru maupun sekolah untuk dapat mengkontekstualisasikannya dengan situasi sekarang dan masa depan.

\section{Penutup}

Pendidikan karakter pada dasarnya adalah pendidikan budi pekerti dengan cara menanamkan nilai-nilai moral kepada peserta didik. Nilai adalah sesuatu yang kita iakan atau kita aminkan dan menjadi panduan untuk bersikap dan bertingkah laku. Nilai moral yang terkandung dalam budaya Jawa yang berwujud tata nilai kehidupan Jawa, seperti norma, keyakinan, kebiasaan, konsepsi, dan simbol-simbol yang hidup dan berkembang dalam masyarakat Jawa, toleransi, kasih sayang, gotong royong, andhap asor, kemanusiaan, nilai hormat, tahu berterima kasih, dan lainnya dapat digunakan sebagai sumber pendidikan karakter. Kebudayaan Jawa memiliki adab, pendidikan, pengajaran, kesenian dan kesusastraan yang penuh ajaran moral, filsafat yang mengandung pemikiran dan kebijaksanaan hidup sampai pada kebatinan dalam hubungan manusia dengan 
Tuhan yang maha pencipta yang sejatinya tidak lekang oleh perubahan jaman.

Model pendidikan karakter berbasis kearifan budaya lokal adalah alternatif model pendidikan yang memiliki relevansi tinggi bagi pengembangan kecakapan hidup (life skills) dengan bertumpu pada potensi kebudayaan lokal di masing-masing daerah, salah satunya budaya Jawa. Dalam model pendidikan ini, materi pembelajaran memiliki makna dan relevansi tinggi sehingga kurikulum yang disiapkan adalah kurikulum yang sesuai yaitu yang mengajarkan peserta didik untuk selalu lekat dengan situasi konkret kebudayaan di masyarakat dan mengembangkannya menjadi moral feeling (rasa/afektif) dan moral action (tindakan) yang terinternalisasi sebagai nilai, etika dan karakter peserta didik. Untuk itu, nilai-nilai budaya Jawa sebagai salah satu kearifan lokal perlu diintegrasikan juga dalam gerakan pendidikan karakter baik di lingkungan pendidikan maupun masyarakat.

\section{DAFTAR PUSTAKA}

Ardhani, Yuli, 2014. "Konsep Pendidikan Multikultural Sebagai Sarana Alternatif Pencegahan Konflik", SOSIODIDAKTIKA: Social Science Education Journal.

Bagir, Zainal Abidin, AA GN Ari Dwipayana dkk., 2016. Pluralisme Kewargaan: Arah Baru Politik Keragaman di Indonesia, Yogyakarta: CRCS.

Damayanti, Deni, 2014. Panduan Implementasi Pendidikan Karakter di Sekolah, Yogyakarta: Araska.

Endraswara, Suwardi, Prof. Dr., 2003. Budi Pekerti dalam Budaya Jawa, Yogyakarta: PT. Hanindita Graha Widya.

Endraswara, Suwardi, Prof. Dr. 2014. Berpikir Positif Orang Jawa, Yogyakarta: Narasi. 
Farikhatin, Anis, dkk., 2016. Mengelola Keragaman di Sekolah: Gagasan dan Pengalaman Guru, Yogyakarta: CRCS.

Ilahi, Mohammad Takdir, 2014. Gagalnya Pendidikan Karakter: Analisis dan Solusi Pengendalian Karakter Emas Anak Didik, Yogyakarta: Ar-ruzz Media.

Isnudi (ed), 2014. Bunga Rampai Kumpulan Makalah Seminar: Diskusi Museum dan Sejarah, Museum Kebangkitan Nasional.

Joesoef, Daoed dan Pontjo Sutowo, 2017. Nilai Ke-Indonesia-an: Tiada Bangsa Besar Tanpa Budaya Kokoh, Jakarta: Kompas.

Komisi Nasional Indonesia untuk UNESCO (KNIU), 2014. Teaching Respect for All: Panduan Menuju Sekolah Bebas Diskriminasi, Jakarta: KNIU.

Khozin, Nur (ed), 2013. Indonesia Rumah Bersama, Musium Kebangkitan Nasional.

Listia, Purwono Nugroho Adhi dan Sartana, 2016. Pendidikan Interreligius: Gagasan Dasar dan Modul Pelaksanaan, Jakarta: CDCC.

Mahfud, Choirul, 2016. Pendidikan Multikultural, Yogyakarta: Pustaka Pelajar.

Muthoifin, 2015. "Ki Hadjar Dewantara: Asas-asas dan Dasar-dasar Taman Siswa dalam tulisan Pemikiran Pendidikan Multikultural Ki Hadjar Dewantara”, Intizar, Vol. 21.

Panjaitan, Ade Putra, Alan Darmawan dkk., 2014. Korelasi Kebudayaan dan Pendidikan : Membangun Pendidikan Berbasis Budaya Lokal, Jakarta: Yayasan Pustaka Obor Indonesia.

Permanadeli, Risa, 2015. Dadi Wong Wadon: Representasi Sosial Perempuan Jawa di Era Modern, Yogyakarta: Pusaka Ifada dan Rifka Annisa.

92 | Adoniati Meyria Widaningtyas 
Simatupang, Maurits, Prof. Dr., 2002. Budaya Indonesia yang Supraetnis, Jakarta: Papas Sinar Sinanti.

Soetarno, 2004. Ragam Budaya Indonesia, Jakarta: Direktorat Pembinaan Pendidikan Tenaga Kependidikan dan Ketenagaan Perguruan Tinggi Dirjen Dikti Depdiknas.

Triyanto dan Adoniati Meyria, 2017. Kertas Posisi Komnas HAM: Transformasi dan Internalisasi Nilai-Nilai HAM dalam Rangka Pembangunan Karakter Bangsa Melalui Sekolah Ramah HAM, Jakarta: Komnas HAM.

Widiastono, Tonny D., 2004. Pendidikan Manusia Indonesia, Jakarta: Kompas dan Yayasan Toyota Astra.

Widiyanto, Hidayat,2010. Prosiding Kearifan Lokal Budaya Jawa sebagai Bahan Ajar Bahasa Indonesia bagi Penutur Asing, BIPA.

Yayasan Cahaya Guru, 2004. "Beragam Bukan Seragam : Panduan Praktis Menumbuhkan Rasa Kebangsaan dan Keragaman", Literati.

Zubaedi, Dr.,MAg.,MPd., 2006. Pendidikan Berbasis Masyarakat: Upaya Menawarkan Solusi terhadap Berbagai Problem Sosial, Yogyakarta: Pustaka Pelajar. 